\title{
Corporate Restructuring and Investment
}

\author{
Dr. Alhassan Ndekugri \\ Allen University, 1530 Harden Street, Columbia, Sc, 29204 \\ E-mail: andekugri@allenuniversity.edu
}

\author{
Received: May22, 2018 Accepted: June 17, $2018 \quad$ Published: June 17, 2018 \\ doi:10.5296/ajfa.v10i1.13183 URL: https://doi.org/10.5296/ajfa.v10i1.13183
}

\begin{abstract}
Corporate Restructuring looked at the strategies employed by managers and leaders of a corporation in times of performance decline to put the corporation back to its normalcy. It is of no doubt that a good performing corporation motivate people to invest. This Research was conducted to investigate how the participants as investors and potential investors want from their Corporate managers and leaders in terms of putting the corporation in good shape. This research Used a survey technique and data was analyzed using SPSS and Excel software. The results showed that there was a relationship between Corporate previous performance and investment decision, at a p-values of 0.779 and 1.000 respectively, which was greater than the significance level of 0.05 we failed to reject the null hypothesis and concluded both Corporate previous performance and Corporate location may have an influence on investors decision making.
\end{abstract}

Keywords: Corporate restructuring, decision making, investment 


\section{Introduction}

Corporate restructuring plays a very important role in the success of a company in times of performance decline. According to Allen and Bonaccorsi di Patti, Ashta and Tolle (2004), Gilson (2001), Lai and SuddarSanam (2001), Weston et al. (2004), restructuring has three main groups: The first is business restructuring (Hillier et al. 2005; Lang et al.,1995; Lasfer et al.,1996; Kang and Shivdasani,1997; Muherin and Boone; Shleifer and Vihny,1992; Weston et al. ,2004). Cost rationalization and finding new market. Financial restructuring (Finnerty,1985 Powell \& Yawson,2008). The third refers to management restructuring (Datta \& Iskandar-Datta,1995; Furtado \& Vijay,1990).

Tricker (2012) said that corporate governance concerns the way power is exercised over corporate entities, including but not limited to board activities and its relationship with shareholders or members, those in charge of managing the enterprise and other stakeholders whose input are necessary to help sustain the company's survival. Brown and Gioai (2002) examine organizational identity challenges in the context of a new division within an organization. Likewise, Corley and Gioai (2004) examine ambiguity in the context of corporate spinoffs and said that corporate brand name changes may help to restore successful operations of the company.

\section{Motivation by this research}

This research was conducted as a result of the many problems engulfing companies of late, for instance, there was no doubt that several well-known companies such as Sears, Kmart, Wall-Mart, Toys R Us, Best Buy, Macy's, JCPenney, Target, Sam's club, and many more other companies not listed here were among the companies that have closed some of their stores because of non-performance. Restructuring if taken would to identify areas of concern to address them instead of permanent closure thereby having an effect on investors and potential investors and employees

\section{Purpose of the research}

The purpose of this research was to investigate how individual's thoughts about Corporate restructuring may have an effect on their future investment decisions

\section{Hypothesis Statement}

\section{Null hypothesis:}

1. A corporate previous performance would have an influence on future investment decision

2. Corporate location would affect investors decisions to invest

\section{Research question}

1. Is there any relationship between Corporate previous performance and investment decision by investors? 


\section{Significance of the study}

It was the firm believe that this research would contribute significantly in the field of academia especially in the area of finance to help discover problems that faced companies such as performance decline due to poor products, leadership crises, employee non-involvement and failure of brand name. Several companies had closed stores because of lack of restructuring techniques and being reactive to problems instead of being proactive. As a result of these many problems that existed in companies, investors and potential investors are reluctant in making a decision to invest for fear of not making profit. For future leaders of a company, this research will help to understand the need of customers, investors and potential investors by being proactive instead of reactive in solving problems relating to their companies.

\section{Literature Review}

Aggarwal and Dahiya (2006) had lookedabout 20 listed stock exchanges by analyzing their performance and conclude that making Change helps to improve performance after listing analogy was also supported by Otchere and Abou-Zied (2008) who also investigated the demutualization process of the Australian stock exchange and concluded that the conversion from mutual to publicly traded exchange was helpful in the stock market liquidity. These results were also confirmed by Azzam (2010) and Oldford and Otchere (2011). According to Brown (2011:164), it very imperative for Organization to respond to challenges in the internal and external environment by introducing some changes that may help to bring about improvement. By undertaking a diagnosis process, organizations are able to identify the problem areas and apply structural, behavioral or technical programs to help put back the company on its feet, (Brown, 2011:136). For this change of programs to work successfully, Armenika and Harris (2009:130) pointed out that the company should involve the employees who are the backbone of the company who must have confidence in the diagnosis of the problems to help in the implementation process.

\section{Why the need to restructure}

Corporate restructuring is initiated with a purpose and requires leadership commitment whereby leaders deals with issues proactively and not reactively, over the years, corporation have continuously been changing to meet the needs of the consumer only when there was a problem that was brought to the attention of management. To avoid reactive ways of problem solving, Ac Brown (2011) said that, random or haphazard are the two types of changes that occur in organization that should take place holistically. A change can bring about some positive or negative results depending on how it is carried out; any change that brings a positive result on the organization will help to meet the objective of that organization, on the other hand, any change that produces a negative result is only sinking the company further. It is no doubt that, corporate America have been in constant search of ways to improve, as a result, management skills and efficiency of employees were most considered besides improving the products for consumers. 


\section{Restructuring to produce quality}

Quality drives business in any organization, when the consumer is satisfied with the product they bought, then they can be sure of coming back next time, as a result, restructuring of organizations will have to take into consideration quality management to gain the trust of customers, for this reason, for an organization to be successful in the restructuring process, every member of the organization should have a clear picture of the measurement of quality (Nica, Monole, and Potcovaru,2016). Developing their position, the work they performed(Morselli,2015). In other parts of the world for instance, in Europe, there had been an established European foundation for quality management which approaches quality based on a widely-recognized model called EFQM excellence model. This model was implemented in more than 30,000 organizations in Europe and had yielded a positive result. The EFQM model explains how quality can significantly contribute to development of an organization and business excellence. Apart from Europe, quality restructuring also occurred in Romania where specialist had provided a relevant picture on how the total quality excellence model is implemented in companies in Romania (Olaru et al.2010), the emphasis was that total quality management was made up of several integration of all functions and processes taking place in an organization in order to meet the need of the customer.

\section{Customer satisfaction in the restructuring process}

Staya (2003) believes that having good customer satisfaction is important in maintaining customer loyalty. Heskett etal (1997) also believe that having customer loyalty is important it has a direct link with the continued survival and strengthening future growth. As a result, for a company to maintain stable profit, there must be a corresponding evaluation of the company from time to time to ensure that issues that hinder company performance are addressed.

In other parts of the world such as the case of Germany, ThyssenKrupp had announced its upcoming portfolio transformation to drastically reduce its dependency on steel production to become a modern technology conglomerate, focusing on business activities such as elevators, refineries, ships, machinery and parts for the automotive industry [3]. Research in the field of business portfolio restructuring has emerged from more general research on corporate restructuring to ensure success over the years and have been considered a response factor in most corporation poor performance (Jonson,1996; Brauer,2006).

\section{Methodology}

This research used a survey technique, a sample size of 100 was administered to students and staff workers in Allen University using a random sampling of the participants. Each participant had the chance of answering the questions to the best of their knowledge, whiles it was required that participants completed the questionnaire within two weeks, some of the participant were not able to do so and other also answered the questions half way. 


\section{Research Design, data analysis and interpretation}

Polit and Hungler (1995:155) described research design as a blue print or outline for conducting the study in such a way that will have maximum control and would exercise over factors that could interfere with the validity of the research results. The research design is the researchers' overall plan for obtaining answers to the research questions guiding the study. Burns and Gove (2001:223) state that designing a study helps researchers to plan and implement the study in a way that will help obtain the intended results. In this research,the questionnaires were designed to follow the survey technique, subjective in nature and allowed participants enough room to express themselves besides just answering the questions

Data analysis play an important role in research so as to convert information gathered during the research into a meaningful and understandable information. this data was analyzed using excel software with color coding technique and SPSS

\section{Interpretation of Results}

Null hypothesis one

\section{A corporate previous performance would have an influence on future investment} decision. According to the results analyzed using non-parametric, one sample test, the outcome showed a value of 0.779 which was more than the significant level of 0.05 , as a result we failed to reject the null hypothesis and concluded that a company previous performance may have an effect on investors decision to invest in a company.

\section{Null hypothesis two}

\section{Corporate location would affect investors decisions to invest}

The results of the non-parametric one sample test showed a result of 1.000 which was also more than the significant value of 0.05 , as a result we also retained the null hypothesis and concluded that Company location whether local or abroad may have an effect on the investors decision to invest.

Table 1. mean comparison of securities

\begin{tabular}{lll}
\hline & & Z-score values \\
\hline Bonds & 1 & -0.65760 \\
Stocks & 2 & -0.49320 \\
Diversify & 3 & 1.15079 \\
\hline
\end{tabular}

As indicated on the table above, a descriptive statistic was also used to compare means of the three securities: Bonds, Stocks and Diversify from the formula $Z=(X-\mu) / \sigma$. The absolute value of the $Z$-score tells the number of standard deviations the security is way from the mean. In this scenario, it means that diversification is about 1.151 standard deviation away from the mean and Bonds and stocks are -0.658 and -0.493 below the mean respectively. 
Table 2. descriptive statistics of securities

Descriptive Statistics

\begin{tabular}{|c|c|c|c|c|c|c|c|c|c|c|}
\hline & & $\begin{array}{l}\mathrm{N} \\
\text { Statistic }\end{array}$ & $\begin{array}{l}\text { Minimum } \\
\text { Statistic } \\
\end{array}$ & $\begin{array}{l}\text { Maximum } \\
\text { Statistic } \\
\end{array}$ & $\begin{array}{l}\text { Mean } \\
\text { Statistic }\end{array}$ & $\begin{array}{l}\text { Std. } \\
\text { Deviation } \\
\text { Statistic }\end{array}$ & $\begin{array}{l}\text { Skewnes } \\
\text { Statistic } \\
\end{array}$ & $\begin{array}{l}\text { Std. } \\
\text { Error }\end{array}$ & $\begin{array}{l}\text { Kurtosis } \\
\text { Statistic }\end{array}$ & $\begin{array}{l}\text { Std. } \\
\text { Error }\end{array}$ \\
\hline V4 & & $\mathbf{0}$ & & & & & & & & \\
\hline $\mathrm{V} 2$ & & 0 & & & & & & & & \\
\hline V3 & & $\mathbf{0}$ & & & & & & & & \\
\hline V5 & & 0 & & & & & & & & \\
\hline V6 & & $\mathbf{0}$ & & & & & & & & \\
\hline V7 & & $\mathbf{0}$ & & & & & & & & \\
\hline V8 & & 3 & 1 & 23 & 9.00 & 12.166 & 1.680 & 1.225 & . & . \\
\hline $\begin{array}{l}\text { Valid } \\
\text { (listwise) }\end{array}$ & $\mathrm{N}$ & 0 & & & & & & & & \\
\hline
\end{tabular}

Table 3. statistic values of the securities

\begin{tabular}{lll}
\hline Statistics & & \\
\hline V8 & Valid & \\
$\mathrm{N}$ & Missing & $\mathbf{3}$ \\
& & $\mathbf{0}$ \\
Mean & $\mathbf{9 . 0 0}$ \\
Std. Error of Mean & $\mathbf{7 . 0 2 4}$ \\
Median & $\mathbf{3 . 0 0}$ \\
Mode & $\mathbf{1}^{\mathrm{a}}$ \\
Std. Deviation & $\mathbf{1 2 . 1 6 6}$ \\
Variance & $\mathbf{1 4 8 . 0 0 0}$ \\
Skewness & $\mathbf{1 . 6 8 0}$ \\
Std. Error of Skewness & $\mathbf{1 . 2 2 5}$ \\
Range & $\mathbf{2 2}$ \\
\hline
\end{tabular}




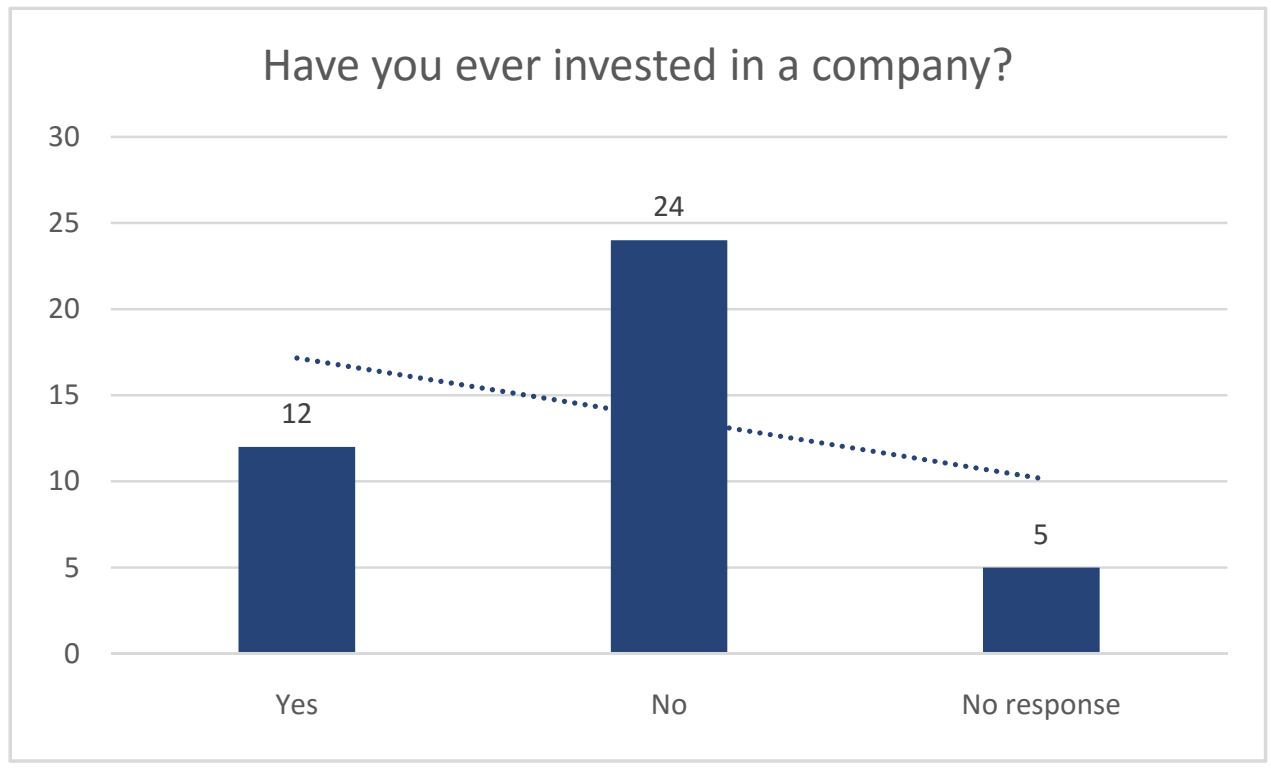

Figure 1. response on investment

From the Figure above, out of the 41 questionnaires that were returned, 24 of the respondents said that they have invested and 12 said they have not invested before, 5 respondents gave no response

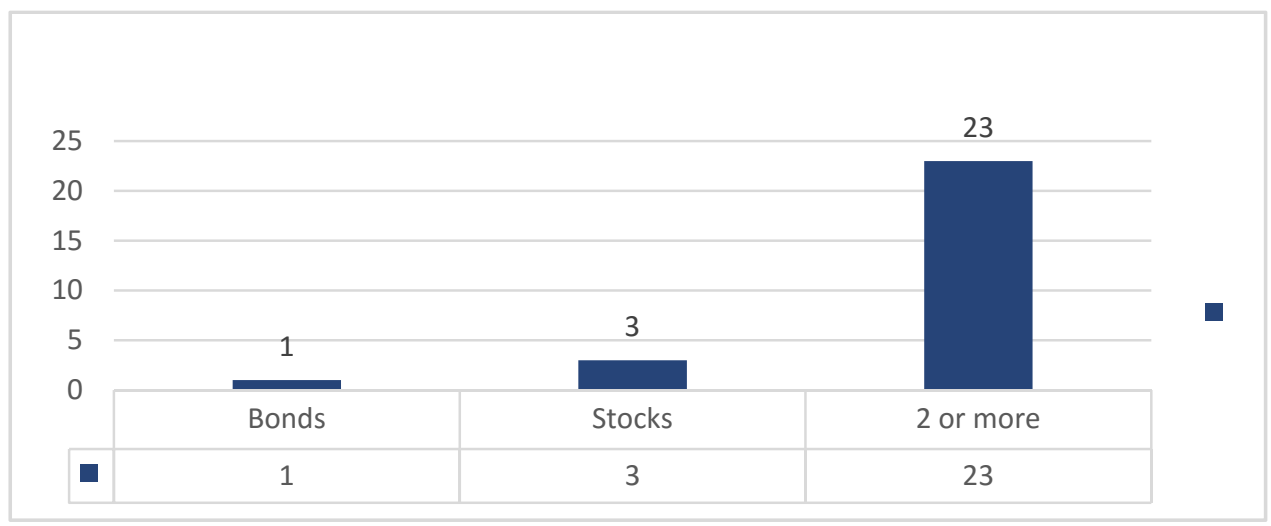

Figure 2. type of security invested

From the figure, of those who said they invested before, 1 person invested in bonds, that is investment in debt securities, giving the investor a fixed income payment over a given period of time. The bond investor can either invest in Government or Corporate, thereby lending money to these entities in return for interest. At maturity, the principal investment is return to the investor. In the bond investment, the face or par value is specified e.g. $\$ 1000$ and the coupon rate is also specified that is used to determine the coupon amount. 3 respondents said they invested in stocks. The stock investor buys shares of a Corporation and become a part owner, this gives the investor an opportunity to take part in decision making such as voting in the case of a common stock investment, however, the preferred stock investor has no voting right but has preference in terms of dividend payment other the common stock holder. While the bond has a maturity date, the stock has no maturity date. 23 respondents said they 


\section{Macrothink}

Asian Journal of Finance \& Accounting

ISSN 1946-052X

2018, Vol. 10, No. 1

invested in more than one security such as stocks, bonds, commercial paper, exchange traded fund...

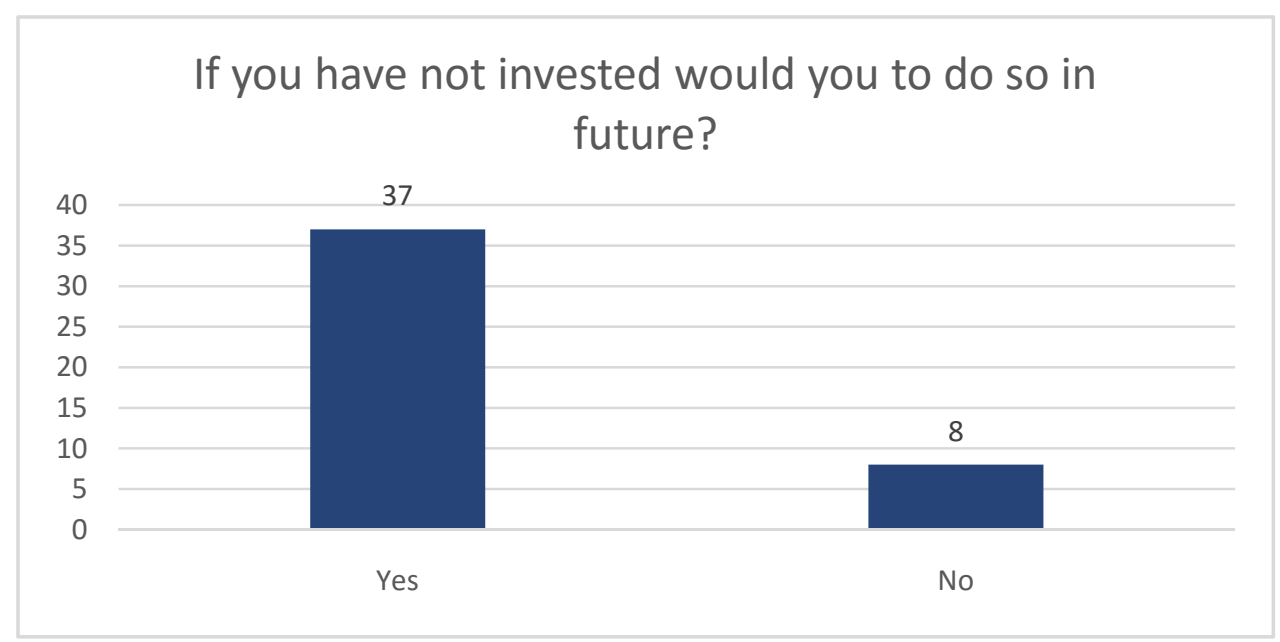

Figure 3. potential investors

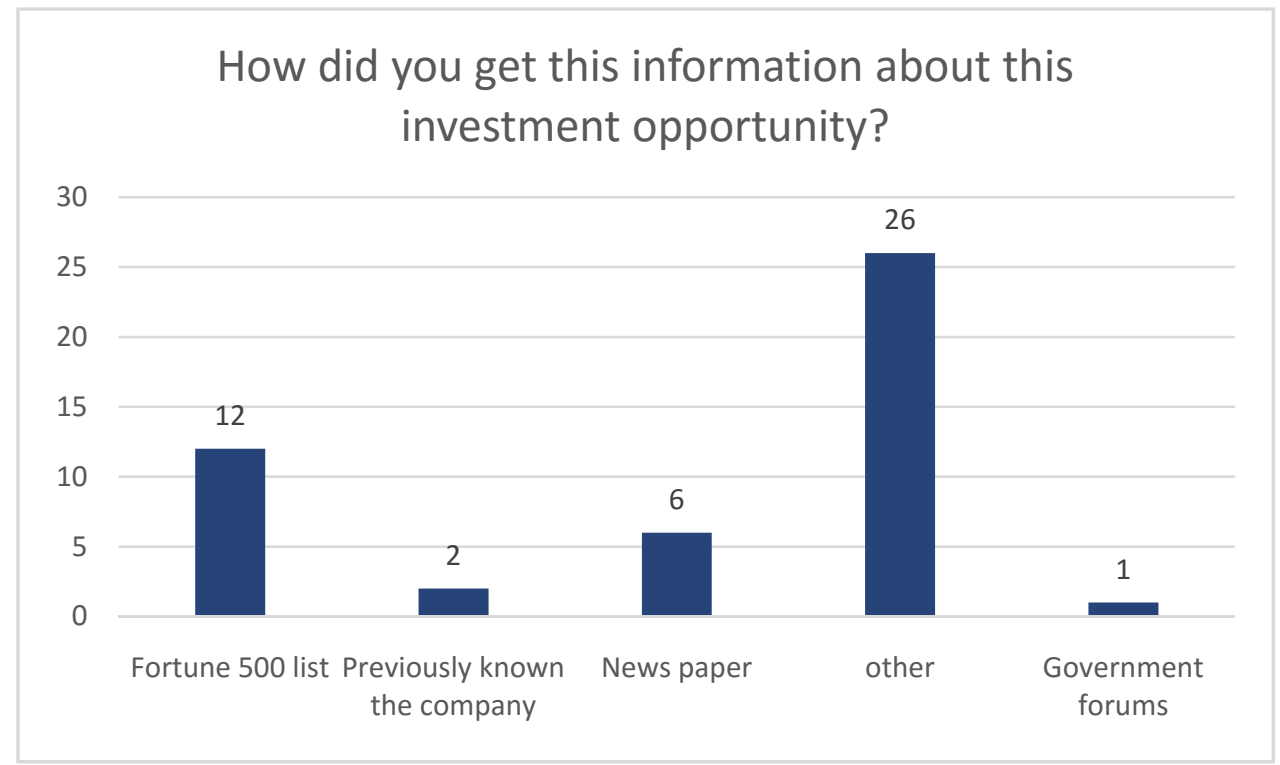

Figure 4. source of information for investment

As far as information is concern for investors, 12 respondents said they got their information for investment on fortune 500 list, 2 respondents said they previously know the company before the investment, 6 respondents said they their information from newspapers, 1 respondent said the information was from Government source and 26 respondents said they got their information from other sources such as family and friends, online search engines, radio... 


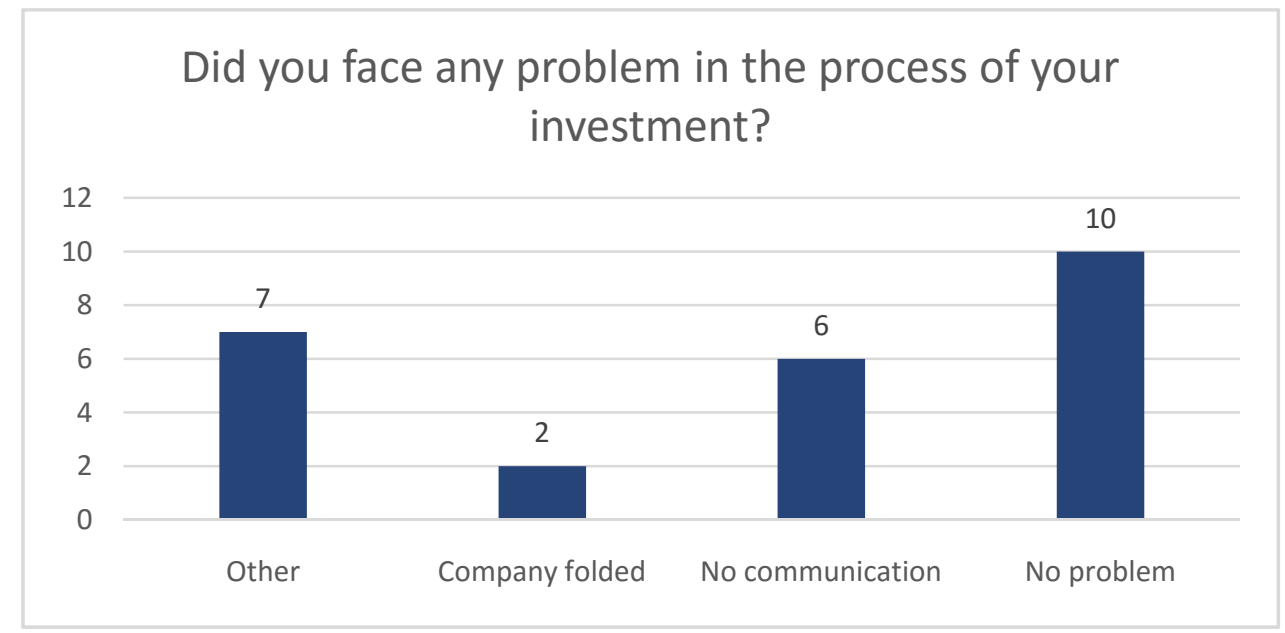

Figure 5. potential problems faced by investors

As far as investment and problem is concern, 10 respondents said that they have not experienced any problem during their period of investment, 6 respondents said that since their investment, there was no communication about the performance of the portfolio and that those companies' communication system was not the best. 2 respondents said their companies folded after their investment and 7 said they experienced other problems such as ROI, and management styles of the company they invested.

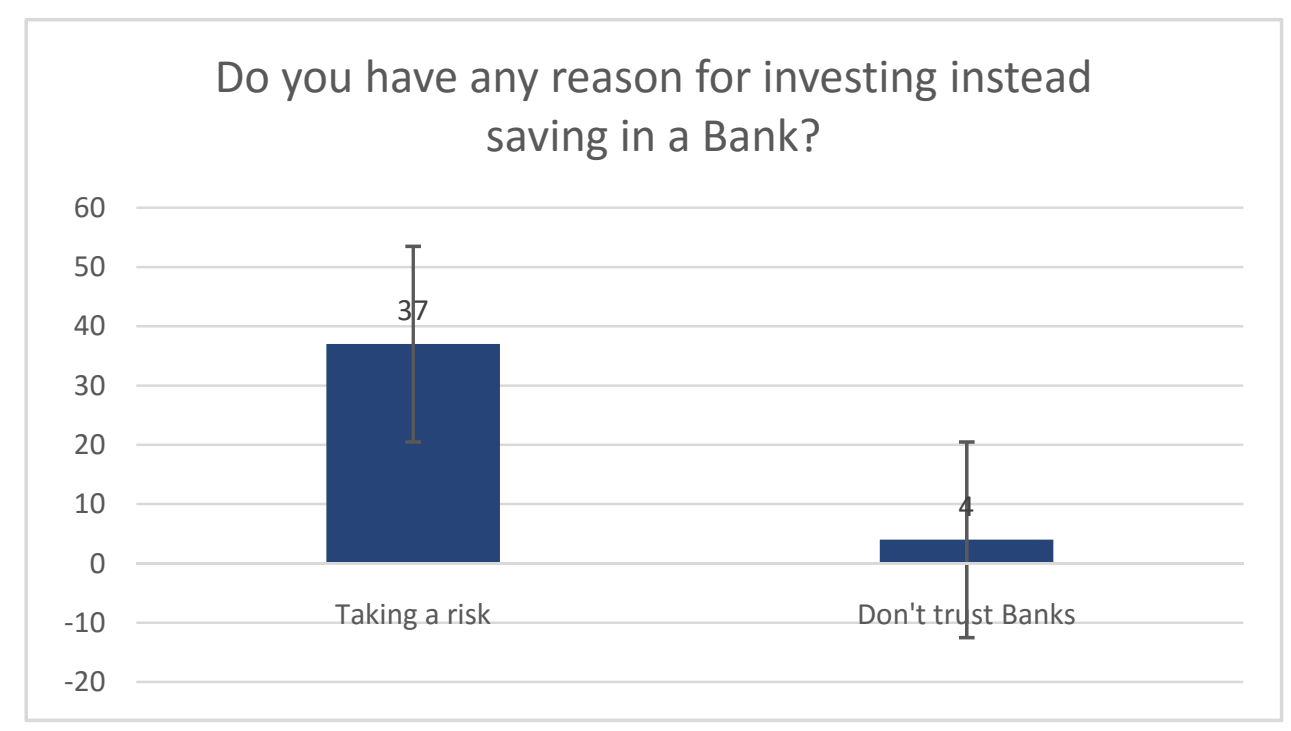

Figure 6. reason for investment

Making a decision to invest instead of saving has some repercussions, as a result, 37 respondents said they had taken the risk to invest instead of savings and 7 respondents said they don't trust banks. 


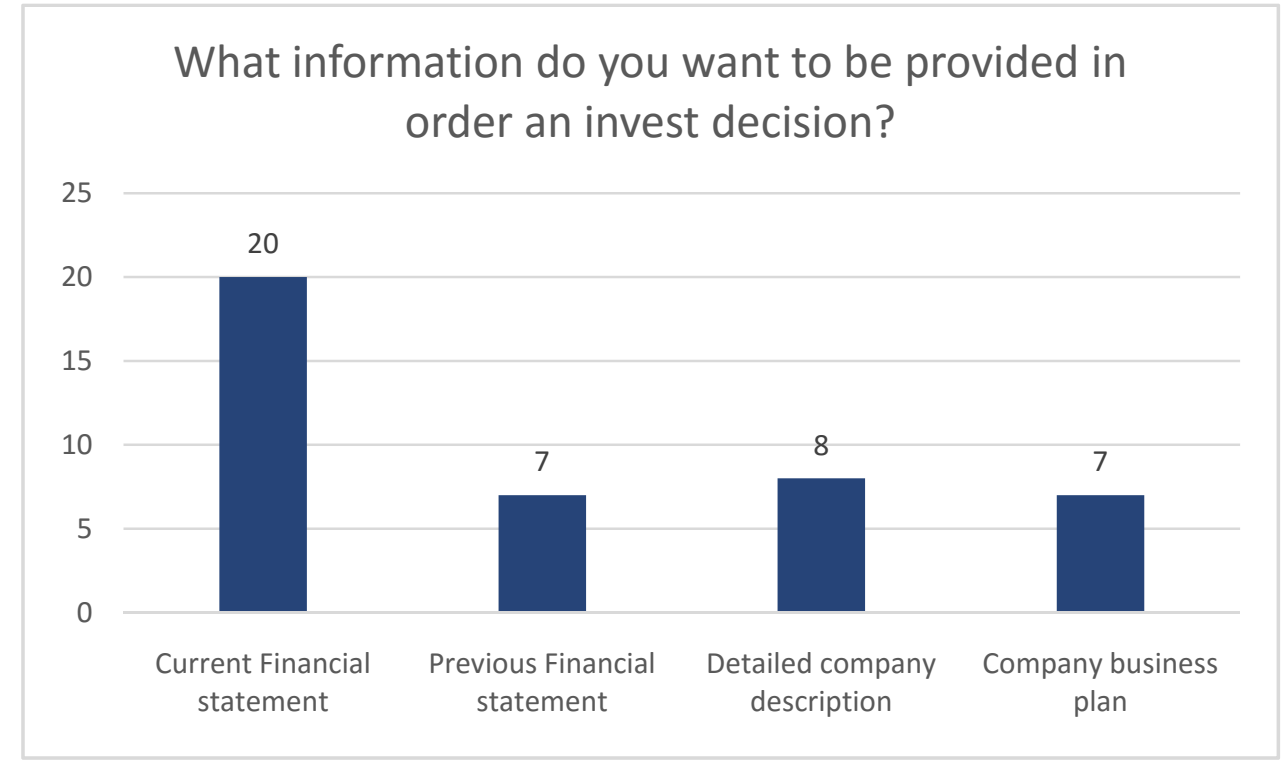

Figure 7. information for investment

In making a decision to invest, some investors need some amount of information to help them, 20 respondents in this survey said that they need the current financial statement to help them understand the company performance before going ahead to invest, 7 of the respondents said they need the previous financial statement and 8 respondents said they need a detailed information to them make an investment decision and 7 respondents said they only need the company's business plan so that they can understand both the short and long run objective of the company they putting their resources in.

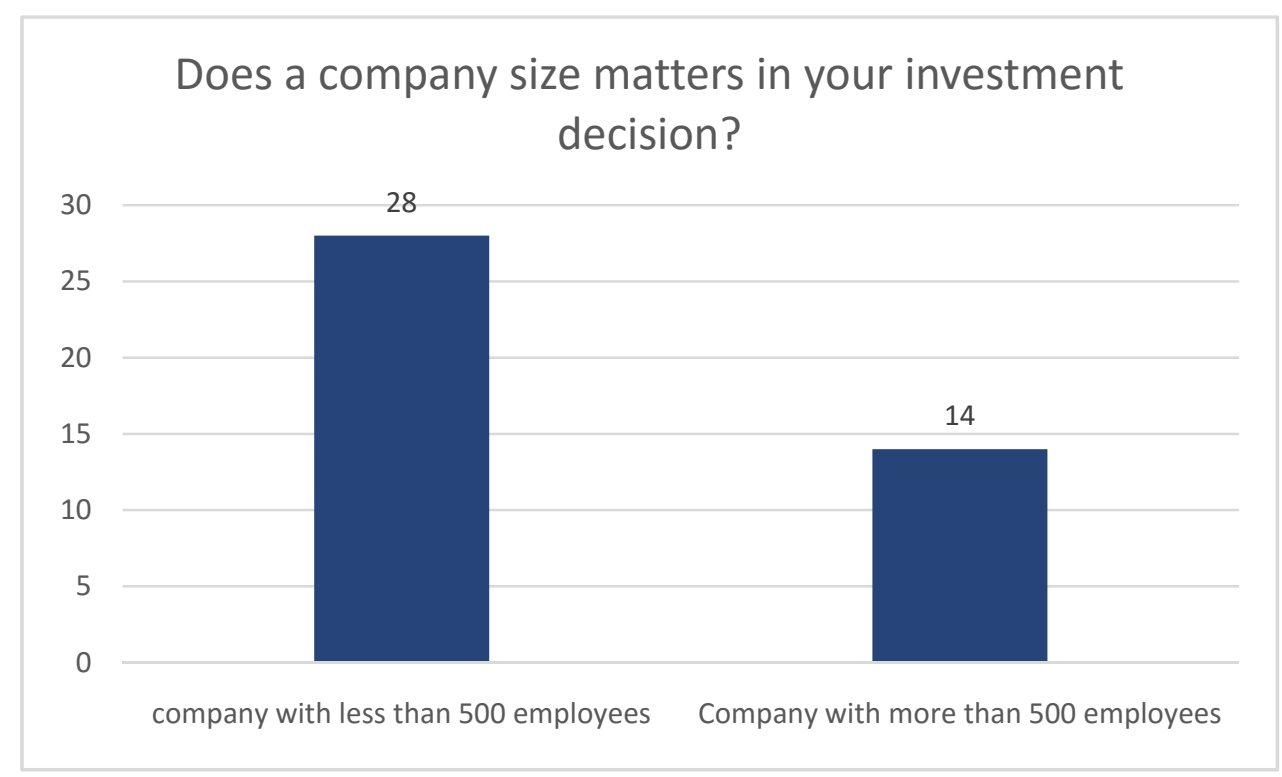

Figure 8. Making decision based on size of company

Most investors have preference on the size of the company they want to invest, in this survey, 28 respondents in this survey said they prefer to invest in a company with 500 employees or less and 14 respondents said they prefer to invest in a company of 500 employees or more 


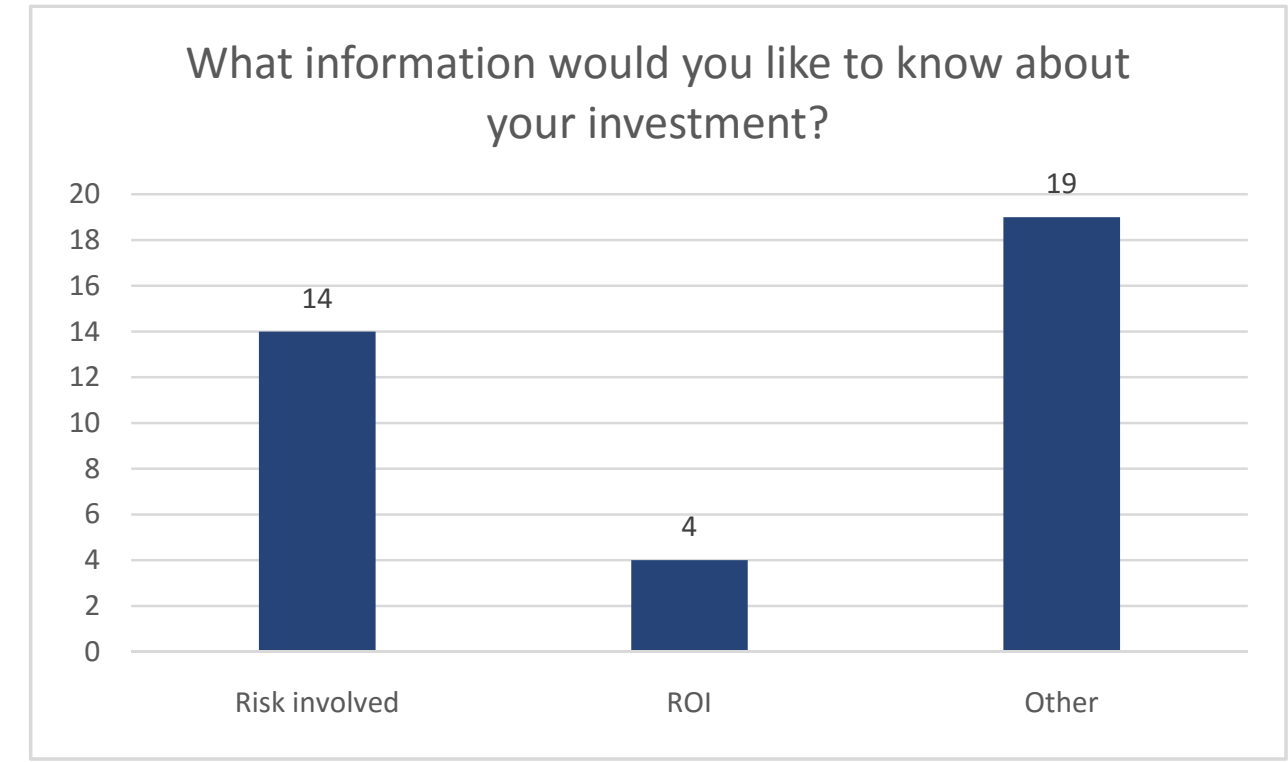

Figure 9. information on investment performance

When people invest they may want to know a certain information regarding their investment, in this survey, 14 respondents said they want to know about the risk involved and how that will affect their money, 4 respondents said they only want know the return on investment, and 19 of the respondents said they need to know other information such as time value of money of their investment, how their wealth will be maximized, and how their investment performs from time to time

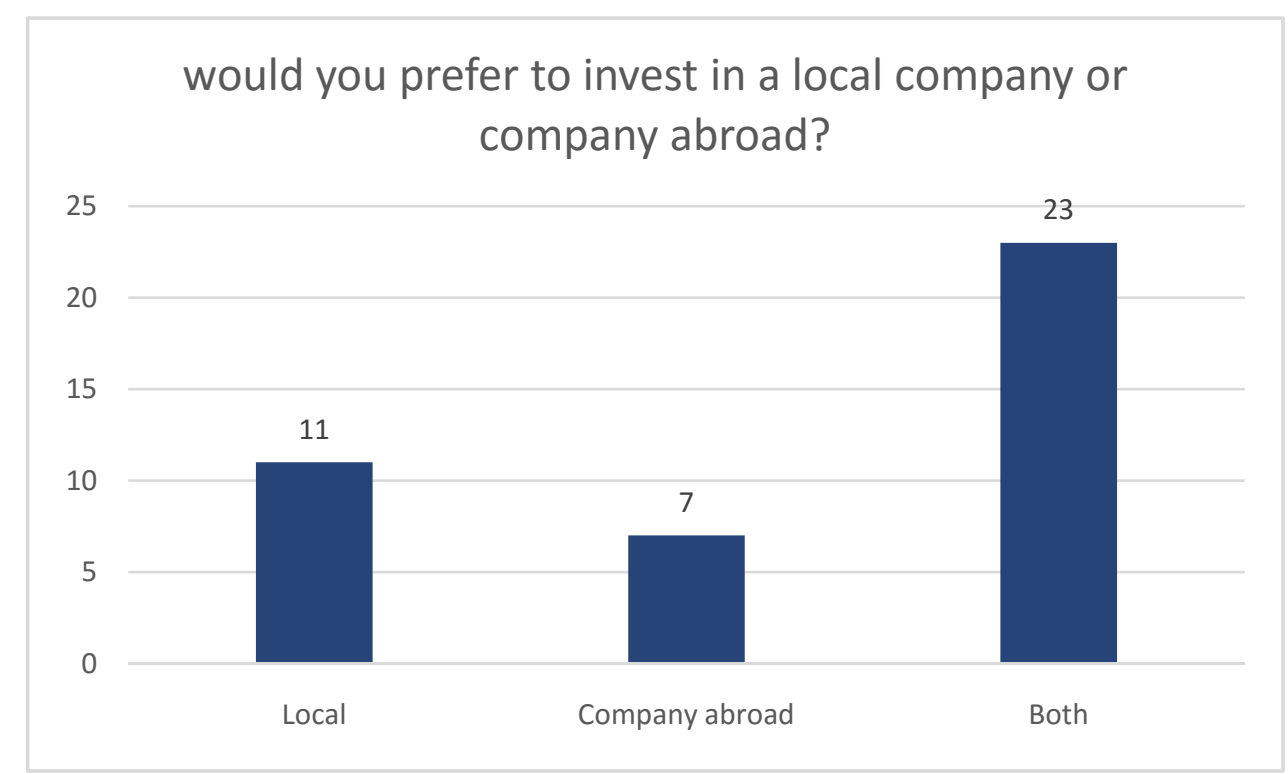

Figure 10. location of company and investment

Most people may have some concerns about locational investment and its prospects, in this survey, 11 respondents said they prefer their investment to be put into companies based in their local country, 7 respondents said they want to invest in companies abroad and 23 respondents said they want to invest in both local and companies abroad 


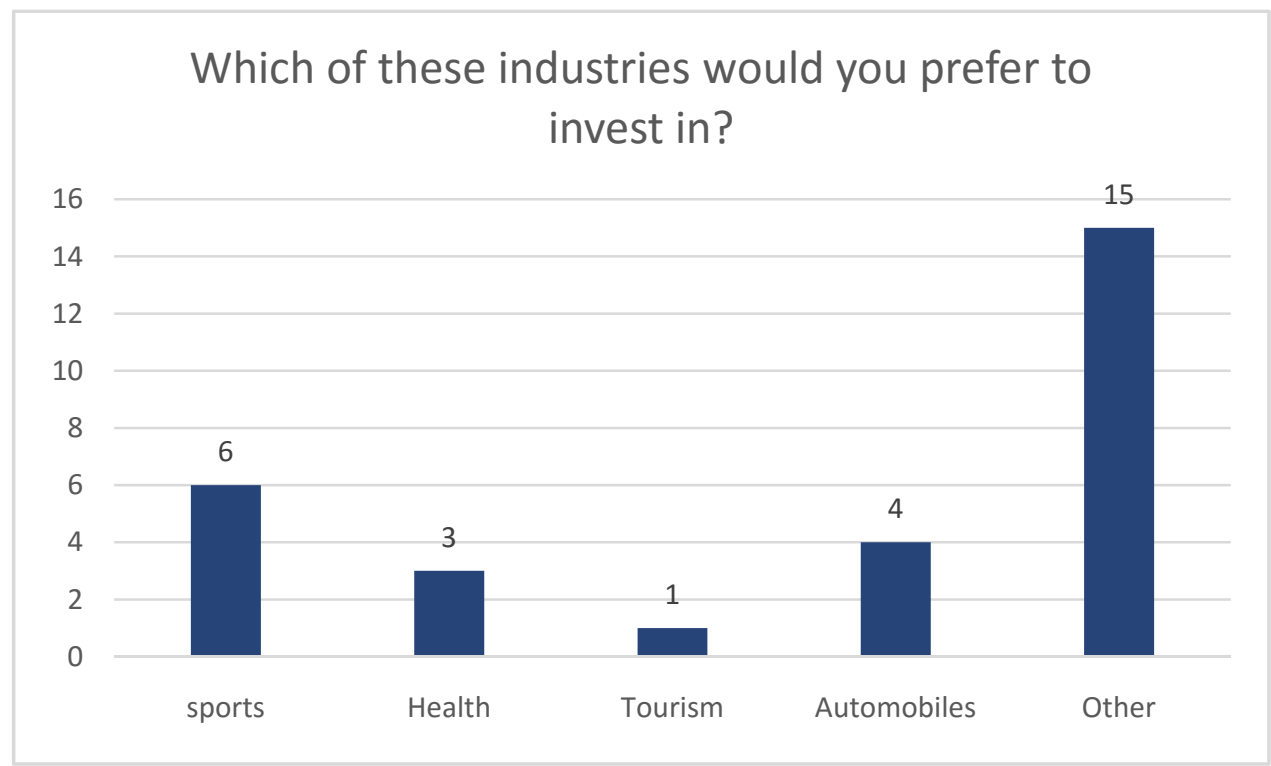

Figure 11. Type of industry and investment

Most investors have Preference on the type of industry to invest, in this survey, 6 respondents said they want to invest in the sports industry, 3 respondents prefer to invest in the health sector, 1 respondent wants to invest in the tourism sector, 4 respondents want to invest in the automobile industry, and 15 respondents wants to invest in other sectors such as restaurants, technology, education, real estates

Of those who responded that they did not invest, they propped further on their future investment decision and most of them said they will invest in the future with a few maintaining that they will not invest at all.

\section{Implication of the study}

This research would serve as a document for Corporation who are in trouble in terms of performance decline and needs restructuring. For the success of any Corporation, the communication aspect was very important by making sure that investors get up to date information regarding the company performance to help investors make an informed decision. Giving a true information of company would be the best way forward instead of false information that does not stand the test of time.

\section{Conclusion}

In all views expressed and data analyzed, most of the participants wanted frequent communications about their investment performance, for instance the risk related to their investment, company financial statement will help to make an informed decision. Most of the participants also wanted to know about the size of the company to understand whether the company is growing and how that would play a role in their investment decision. Others also said that they would invest in a company irrespective of location, whiles some also said that location would influence their decision to invest. 


\section{References}

Abed, S., \& Roberts, C. (2011). Methods for scoring Annual reports narratives: The case of the extent of forward looking information, EAA, Rome

Aggarwal, \& Dahiya, S. (2006). Demutualization and public offering of financial exchange. Journal of applied corporate finance, 18, 105-113.

Ahrens. (2004). Refining research questions in course of negotiating access for fieldwork in Humphrey. C. and Lee, R.(Eds), The real-life guide to accounting Research: A behind the scenes view using Qualitative Research method, Elsevier, Oxford, PP.295-307. https://doi.org/10.1016/B978-008043972-3/50019-0

Al-Najjar, B. and Abed, S. (2014). The association between disclosure of forward looking information and corporate governance mechanism: Evidence from the UK before the financial crisis period. Managerial auditing, 29(7),578-595. https://doi.org/10.1108/MAJ-01-2014-0986

Angulo, L. et al. (2014). The London stock exchange strategic corporate governance restructuring after Demutualization. Journal of applied business research, 30(1). Laramie.

Angulo, L.P., Slimane, F.B., \&Alidou, D. (2014). The London stock exchange: strategic corporate governance restructuring after demutualization. Journal of applied business research, 30(1). Laramie

British Educational Research Association. (2009). Educational Research: Powerful definitions of research. Retrieved from http://tinyurl.com/26yvalr

Higgs, J. (2001). Charting standpoints in qualitative research. Critical moments in qualitative research, 14(1), 44-67.

National Institute of health. (2009). NIH roadmap for clinical research: Translational research retrieved from http://tinyurl.com/3yt6a4d

Argosy University. (2016). Doctoral research guide for studies, planning, and writing Doctoral research.

Ashta, A., \& Tolle, L. (2004). Criteria for selecting restructuring strategies for distressed or declining enterprise, group ESC Dijon Bourgogne, Department of law, finance and control, Dijon.

Azzam, I. (2010). Stock exchange demutualization and performance. Global finance journal 21, 211-222. https://doi.org/10.1016/j.gfj.2010.06.007

Brown. (2011). An experiential approach to organizational development, $8^{\text {th }}$ ed, Pearson education

Bruni, A. (2006). Access as trajectory: Entering the field in organizational ethnography, 9(3), 129-144. https://doi.org/10.3917/mana.093.0137 
Chang, K.P., \& Graham, G (2012). E-business strategy in supply chain collaboration: An empirical study of B2B E-commerce project in Taiwan. International journal of electronic business management, 10(2), 101-112. Hschindu.

Datta, S., \& Iskandar-Datta, M.E. (1995). Reorganization and financial distressed: An empirical investigation. Journal of financial research, 18(1), 15-32. https://doi.org/10.1111/j.1475-6803.1995.tb00208.x

Dean, J. W., \& Bowen, D. (1994). Management theory and total quality: improving research and practice through theory development. Academic of management review, 19(3), 392-418. https://doi.org/10.5465/amr.1994.9412271803

DeCuir-Gunby, J.T., Patricia, L.M., \& Allison, W.M. (2011). Developing and using a codebook for the analysis of interview data: An example from a professional development research project. Field methods, 23(2), 136-155. https://doi.org/10.1177/1525822X10388468

Dowling, G.R., \&Garberg N.A. (2012). Keeping score: The challenges of measuring corporate reputation in Barnett, M.L. and Pollock T.G.(Ends), Oxford Hand book of corporate reputation, Oxford University press, Oxford, 34-68. https://doi.org/10.1093/oxfordhb/9780199596706.013.0003

Elaine, W. (2002). Dealing with Data: Using NVivo in the qualitative data analysis process

Habib, F., Estesam, I. Ghaddusifar, S.H., \&Mohajeri, N. (2012). Corresponding analysis: A new method for analyzing qualitative data in architecture. Nexus network journal, 14(3), 517-538. Dordrecht .https://doi.org/10.1007/s00004-012-0129-1

Hiller, D., Mccolgan, P., \&Werema, S. (2005). Asset sales, operating performance and firm strategy: An empirical analysis, University of Stratethelyde, Department of accounting and finance, Scotland

Housley, W., \& Robin, J.S. (2011). Telling the CAQDAS code: Membership categorization and the accomplishment of 'coding rules' in research team talk. Discourse studies, 13(4), 417-434. https://doi.org/10.1177/1461445611403258

Joudeh, J.M.M. (2017). The impact of service quality dimensions upon customers' satisfaction: An empirical study applied in the Jordanian mobile telecommunication sector. International review of management and business research, 6(1), 184-198. Peshawar.

Karjalainen, M. Niemisto, C., \& Hearn, J. (2015). Unpacking the problem of research access(es): The case of large knowledge-intensive international consultancies. Qualitative research in organizations and management, 10(3).Braford.https://doi.org/10.1108/QROM-12-2013-1189

Kerr, R. Garvin, J. Heaton, N. and Boyle, E. (2006). Emotional intelligence and leadership effectiveness. Leadership and organization development journal, 27(4), 265-279. https://doi.org/10.1108/01437730610666028 
Lai, J., \& Sudarsanam, S. (2001). Corporate financial distressed and turnaround strategies: An empirical analysis. British journal of management, 12(3), 183-199. https://doi.org/10.1111/1467-8551.00193

Leonard, D. (2015). Using business excellence to change our roots: perspective Oakbrook business review, 1, 4-7

Leonard. and McAdam. (2003). The strategic impact and implementation of TQM. The TQM magazine, 14(1), 51-56

Liao, J. (2005). Corporate restructuring, performance and competitiveness: An empirical examination. Competitiveness review, 15(1), 33-48.

Morelia. (2015). The decision-making process between convention and cognition. Economics and sociology, 8(1), 205-221

Nica, E. Manole, C., \& Portcovaru, A.M. (2016). Competition in the worldwide work place; journal of self-governance and management economics, 4(3), 73-79

Noriah, M.I., \& Abu, Y.A.B. (2012). Qualitative data management and analysis using NVivo: A.

Otchere, I. (2006). Stock exchange self-listing and value effects. Journal of corporate finance, 12,926-953. https://doi.org/10.1016/j.jcorpfin.2006.02.003

Otchere, I., \& Abou-Zied, K. (2008). Stock demutualization, self-listing and performance: The case of Australian stock exchange. Journal of banking and finance, 32,512-525. https://doi.org/10.1016/j.jbankfin.2007.07.011

Panday, I.M. (2015). Agency behavior and corporate restructuring choices during performance decline in emerging economy. International journal of managerial finance, 11(2), 244-267. https://doi.org/10.1108/IJMF-03-2014-0035

Pritchard, K. (2011). From being... where? Qualitative research in organizations and management, 6(3), 230-245. https://doi.org/10.1108/17465641111188402

Probhakaran, S., \&Staya, S. (003). An insight into service attributes in banking sector. Journal of services, $8(1)$, 24-34

Research mythology (n.d). Retrieved from uir.unisa.ac.za/bit stream/handle/10500/2127/04chapter3.pdf

Schonhar, S.,Pidun, U., \& Nippa, M. (2014). Transforming the business portfolio: How multinationals reinvent themselves. The journal of business strategy,35(3), 4-17. Boston.https://doi.org/10.1108/JBS-06-2013-0041

Sirkin, Hrold, Keenan, Perry, Jackson, \& Alan. (2005). The Hard Side of change management.Harvard business review, reprint Ro510c, pp.1-10

Tricker, B. (2012). Corporate governance: principles, policies. Oxford: Oxford University press 
Wepener, M., \& Boshoff, C. (2015). An instrument to measure the customer based corporate reputation of large service organizations. The journal of service marketing, 29(3), 163-172.

Yawson, A. (2008). Interaction effects of restructuring decisions on operating profit following performance shocks. journal of economics and business, 61(3), 216-237

ZONDI, S.N., \& Mutambara, E. (2016). An investigation into the impact of organizational change strategy at company X. International review of management and business research, 5(4), 1288-1312.Peshawar.

Ndekugri, A. (2017). Corporate Restructuring. 